\title{
Human responses to the Ilopango Tierra Blanca Joven eruption: excavations at San Andrés, El Salvador
}

\author{
Akira Ichikawa ${ }^{1,2, *}$ \\ ${ }^{1}$ Department of Anthropology, University of Colorado Boulder, USA \\ ${ }^{2}$ Research Centre for Cultural Heritage and Texts, Nagoya University, Japan \\ * Author for correspondence akira.ichikawa@colorado.edu
}

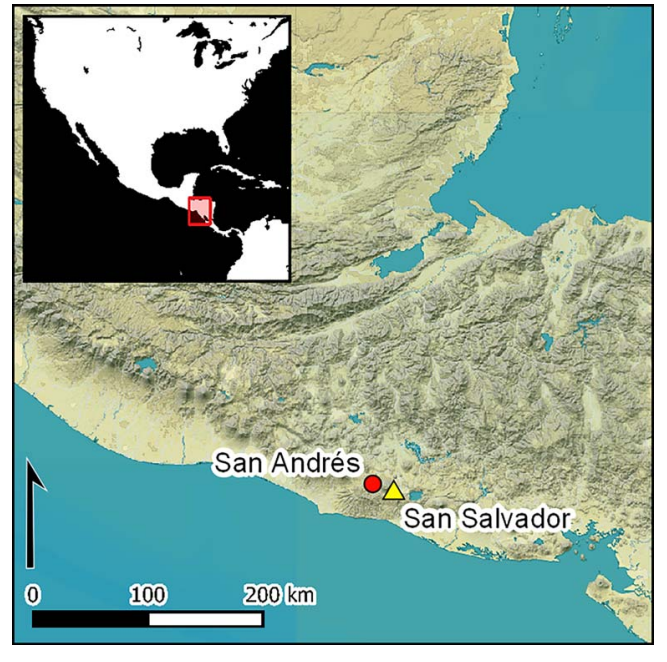

Human responses to catastrophic natural events form an important research theme in archaeology. Using excavation and radiocarbon data, this article investigates the socio-cultural impact of the midfirst-millennium AD Tierra Blanca Joven eruption at San Andrés, El Salvador. The data, along with an architectural energetic analysis of the Campana structure at San Andrés, indicate that survivors and/or re-settlers made considerable efforts to construct monumental buildings immediately following the eruption, using volcanic tephra as construction material. Such re-building played important religious, social and political roles in human responses to the eruption. The study contributes to discussions about human creativity, adaptation and resilience in the face of abrupt environmental change.

Keywords: El Salvador, San Andrés, Early Classic period, Ilopango eruption, monumental building

\section{Introduction}

Understanding how humans have responded to abrupt environmental change in the past is an important and challenging topic in recent archaeological research (e.g. Cooper \& Sheets 2012; Kintigh et al. 2014: 18). This article focuses on the Tierra Blanca Joven (TBJ) eruption in the Ilopango Caldera, El Salvador; it is considered the largest Holocene eruption in Central America (Dull et al. 2019; Pedrazzi et al. 2019). The huge volume of tephra generated had far-reaching social and environmental impacts across an extensive region around the volcano. Additionally, the TBJ eruption is considered to have been a trigger of the 'Maya Hiatus'-a phenomenon characterised by a clear reduction in dated stelae-c. AD 534-593, and the cause of global climatic cooling in the Northern Hemisphere during the mid-sixth century

Received: 29 August 2020; Revised: 11 January 2021; Accepted: 25 January 2021

(C) The Author(s), 2021. Published by Cambridge University Press on behalf of Antiquity Publications Ltd. This is an Open Access article, distributed under the terms of the Creative Commons Attribution licence (https://creativecommons. org/licenses/by/4.0/), which permits unrestricted re-use, distribution, and reproduction in any medium, provided the original work is properly cited. 
(e.g. Gunn 2000; Dull et al. 2019; for further discussion of the date and impact of the TBJ eruption, see Sharer 1978; Dull et al. 2001, 2010; Sheets 2012; Lohse et al. 2018).

In Maya archaeology, the date and impact of the TBJ eruption have long been the subject of controversy. Although the widely distributed TBJ tephra serves as a temporal horizon maker, to pinpoint the date of the eruption through radiocarbon dating is challenging due to the calibration curve plateau at around cal $\mathrm{AD} 420-540$, leading to large uncertainties in calibrated dates (Dull et al. 2001, 2019). The latest research argues that the eruption probably occurred in AD 539/540, a date estimated using 100 new radiocarbon dates and Bayesian modelling techniques performed on three tree trunks completely buried by TBJ tephra (Dull et al. 2019: 12). Although other research suggests that the eruption may fall within the range cal AD 270-400, based on data from Lake Amatitlán in Guatemala (Lohse et al. 2018: 390 ), this article uses $\mathrm{AD} \mathrm{539/540} \mathrm{as} \mathrm{the} \mathrm{eruption} \mathrm{date} \mathrm{because} \mathrm{of} \mathrm{the} \mathrm{compelling} \mathrm{case} \mathrm{pre-}$ sented by Dull et al. (2019).

This study seeks to clarify the social impact of this catastrophe on the south-eastern Maya area, as well as on the broader Maya civilisation (Sharer 1978; Demarest 1988; Dull et al. 2001, 2019). Previous studies have resulted in two different interpretations of the impact. Some scholars have argued that Late/Terminal Preclassic (400 BC-AD 250) societies suffered population decline and societal collapse due to the immediate and long-term effects of the TBJ event. These scholars rely on an earlier date for the eruption, and cite the lack of Early Classic (AD 250-600) material in western El Salvador, the south-eastern Pacific coast and the Piedmont zone of Guatemala (e.g. Kosakowsky et al. 2000; Dull et al. 2001). They conclude that the region was largely abandoned, with settlers only re-inhabiting it one or two centuries after the eruption (Sharer 1978; Demarest 1988; Dull et al. 2001). If the eruption dates to AD 539/540, however, this suggests a shorter period of societal reorganisation than previously imagined, with most of western El Salvador fully resettled by the middle of the seventh century, as well as the completion of some monumental construction projects (Dull et al. 2019: 12).

The nature of human responses to and recovery from this catastrophic volcanic event remains under investigation. While volcanological, geological and radiocarbon data have increased considerably over the past 20 years, archaeological data related to the TBJ event have not grown substantially since the 1990s. Attempts to correlate abrupt environmental change with social decline or development are complicated by several factors, including population size, social complexity and economic and political inequalities (Coombes \& Barber 2005). Furthermore, it can be difficult to measure the impact of these disasters on human societies based only on the magnitude of such hazardous events (Sheets 2012). Thus, to assess the impact of the TBJ eruption on local communities, more archaeological data with clear chronological context in relation to the event are required.

This article examines how human societies responded to the TBJ eruption, using archaeological and radiocarbon data from the primary regional centre-San Andrés-in the Zapotitán Valley, situated approximately $40 \mathrm{~km}$ west of the Ilopango Caldera (Figure 1). The resulting data suggest that a monumental public building project, requiring considerable labour investment, was initiated within 5-30 years after the TBJ eruption (or within 80 years at most), using a large volume of TBJ tephra as construction material. This project was crucial in re-establishing social and political order in the region. Additionally, the results contribute to a discussion of human resilience to unpredicted catastrophes. 


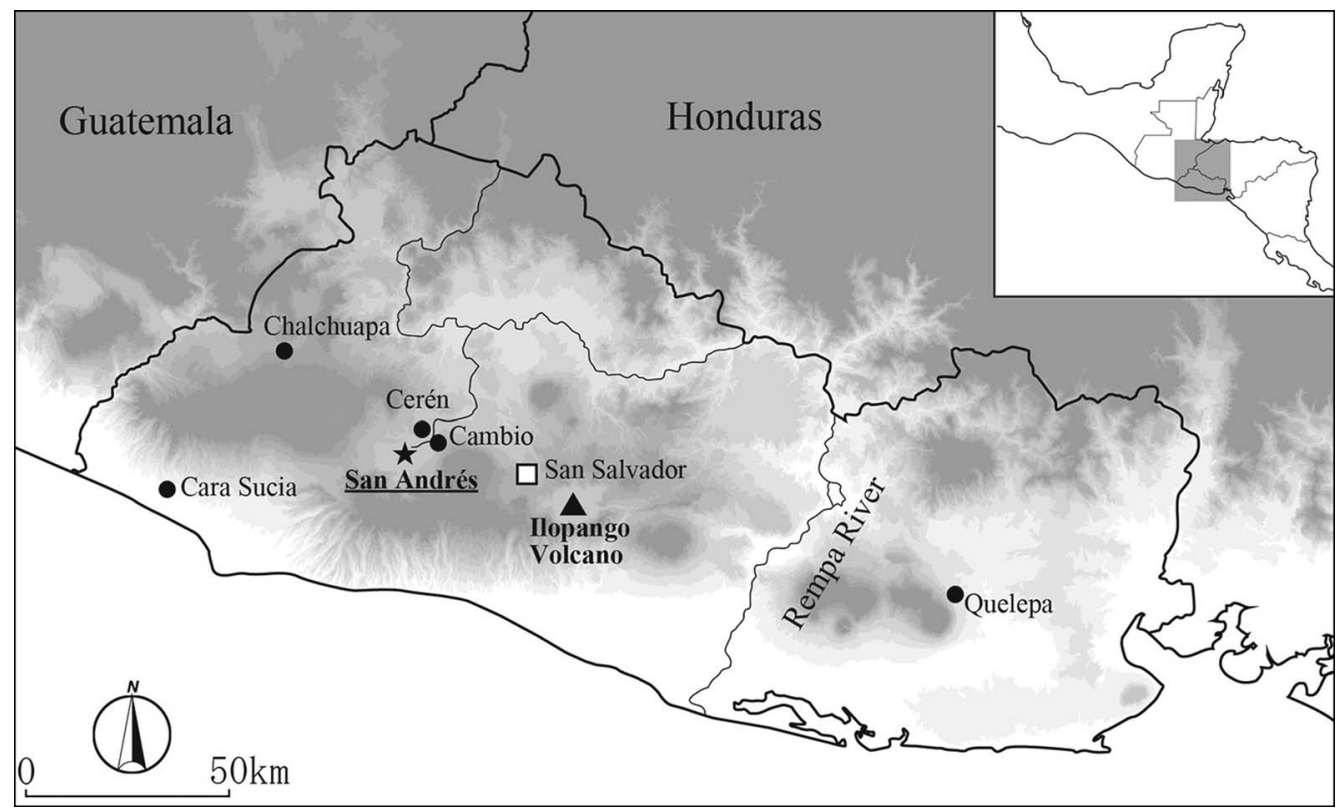

Figure 1. Map of El Salvador showing the locations of San Andrés and the Ilopango Caldera (map by A. Ichikawa).

\section{San Andrés in the Zapotitán Valley}

Established on an alluvial plain at an altitude of approximately $460 \mathrm{~m}$ asl, San Andrés is located close to the confluence of the Sucio and Agua Caliente rivers in the Zapotitán Valley in central-western El Salvador (Figure 1). San Andrés is situated just $5 \mathrm{~km}$ east of the old Laguna (or Lake) Ciega de Zapotitán and around $5 \mathrm{~km}$ south of Cerén, a small village that was buried by the Loma Caldera eruption in the early or mid-seventh century. Analyses of ceramic assemblages from San Andrés (Amaroli 1996; Begley et al. 1997; Ichikawa \& Guerra Clará 2018) trace back occupation to the Middle Preclassic period (1000-600 BC), extending into the Early Postclassic period (c. AD 1200). The settlement became a primary regional centre during the Late Classic period (AD 600-900). The core architectural complex of the site comprises the Acropolis, the North Plaza, the Campana structure and several low rectangular mounds (Figure 2). The site layout (the results of extensive excavations at the Acropolis (Boggs 1943)) and an impressive cache that included a so-called 'eccentric flint' (or elaborate lithic object) found at Structure 7 demonstrate that San Andrés interacted with the Copán dynasty during the Late Classic period (Boggs 1943; Mejía 1984). Nevertheless, we do not yet understand when and how monumental public building projects were initiated, developed and terminated during this time.

The Zapotitán Valley is surrounded by impressive volcanos such as the San Salvador and Santa Ana volcanic complexes. Hence, during the pre-Hispanic period, humans witnessed multiple volcanic events, including the TBJ, Loma Caldera, El Boquerón and other small-scale eruptions (Ferrés et al. 2011). Given this geological setting, the interaction between these volcanic events and human activities is a key research topic for understanding 


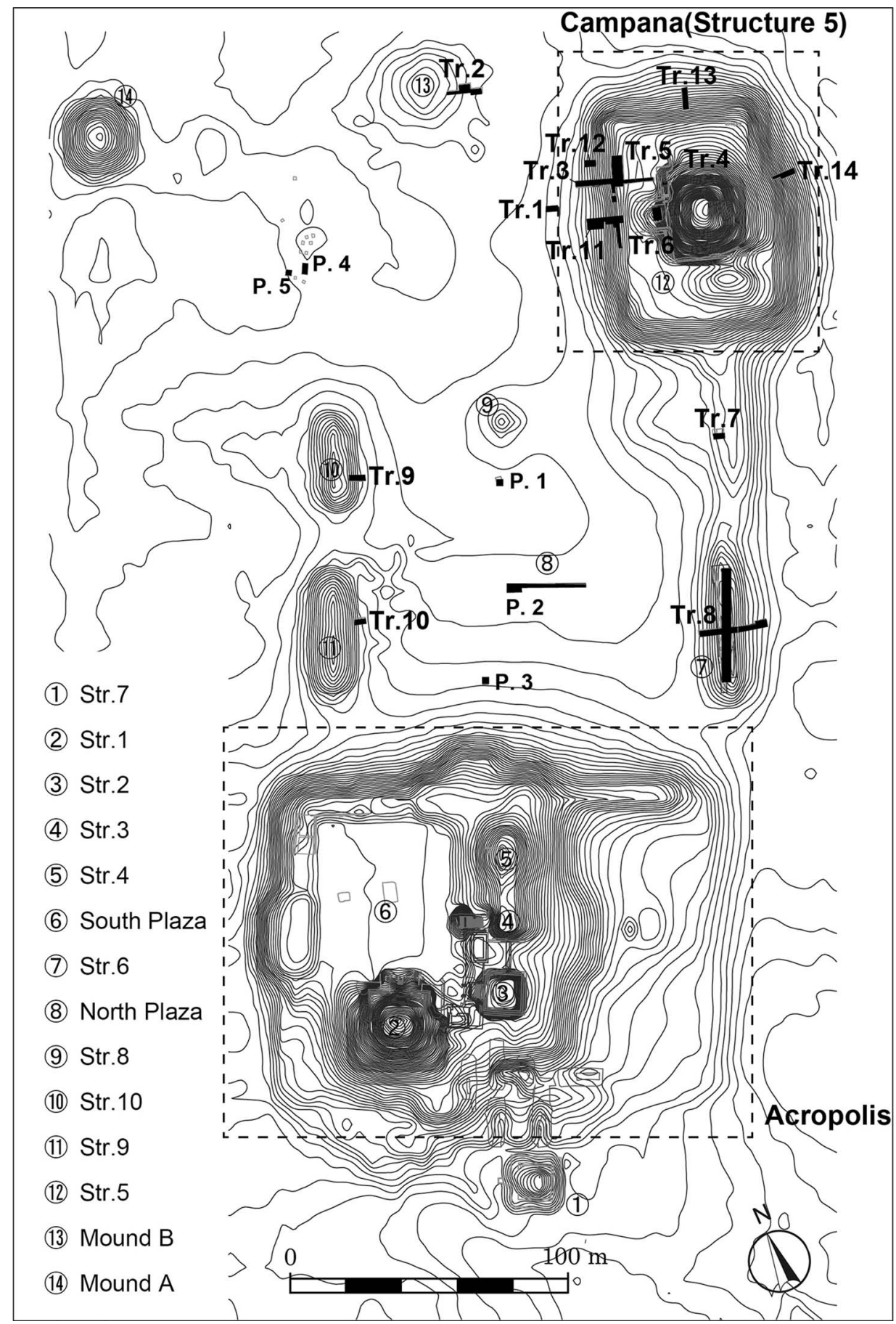

Figure 2. The main architectural complex at San Andrés (fgure by A. Ichikawa).

(C) The Author(s), 2021. Published by Cambridge University Press on behalf of Antiquity Publications Ltd 
social dynamics in the region (Sheets 1983). The Zapotitán Valley, including San Andrés, is situated within the area devastated by tephra from the TBJ eruption (Sheets 1983; Ferrés et al. 2011). While the pyroclastic flow did not greatly affect the valley, pumice- and ash-fall deposits average $0.5 \mathrm{~m}$ thick (Ferrés et al. 2011: 841). Despite extensive archaeological surveys of the valley (Black 1983) and a long history of investigations at Cerén (Sheets 1983, 2002), archaeological research related to the impact of the TBJ eruption in the Zapotitán Valley is limited.

\section{The Campana structure: excavations and radiocarbon dating}

\section{The Campana structure excavations}

Topographic mapping and excavation show that the Campana structure comprises a pyramidal form atop a platform. In its final and extant configuration, the platform measures approximately $85 \times 65 \mathrm{~m}$, and $7 \mathrm{~m}$ in height, and the pyramidal structure measures approximately $35 \times 40 \mathrm{~m}$, and $13 \mathrm{~m}$ in height. The total volume of the Campana structure-the largest in the valley_is approximately $33000 \mathrm{~m}^{3}$. Begley et al. (1997) excavated a pyramidal structure on the west side of the platform, revealing several architectural phases corresponding to the Late Classic and Postclassic periods. From 2015-2019, the author and colleagues excavated the Campana structure to identify the initial construction phase. We also excavated the North Plaza, along with four low, rectangular mounds surrounding the Plaza, in order to understand the architectural development of the site (Figure 2 and Table S1 in the online supplementary material (OSM)).

The material evidence recovered from beneath the TBJ tephra is more abundant than previously thought (Black 1983): 30 per cent of the entire ceramic assemblage from the 2015-2019 seasons (8008 of 26351 sherds) was retrieved from beneath the tephra. These ceramic types date predominantly to the Late and Terminal Preclassic periods ( $400 \mathrm{BC}-$ $A D$ 250). Despite other notable evidence previously found beneath the TBJ tephra, such as agricultural fields (McKee 2007, 2011), excavations at San Andrés have failed to reveal monumental architecture from this period. The only local site with possible ceremonial architecture is Cambio, located approximately $4 \mathrm{~km}$ to the north (Chandler 1983). Thus, presumably, prior to the TBJ eruption, San Andrés was a village without any monumental structures.

Excavation data indicate that the first monumental public building at San Andrés, that is, the Campana structure, was constructed after the TBJ eruption. It was built using a combination of earth fill and redeposited TBJ tephra (Figure 3A). The primary TBJ tephra is divided into eight units, one of which (Unit VII of Dull et al. 2019; Unit G of Pedrazzi et al. 2019) is a white, fine-ash layer that is frequently recognised across El Salvador. Excavations carried out in different areas at San Andrés confirm that the thickness of the primary TBJ tephra varied from $0-0.52 \mathrm{~m}$ (Figure 4 and Table S1). This first monumental public building, filled with earth and TBJ tephra, was renovated at least three times, as indicated by three hardened clay layers (floors 2, 3 and 4 in Figure 3A), and reached a final height of $6 \mathrm{~m}$ (Figure $3 \mathrm{~A})$. 


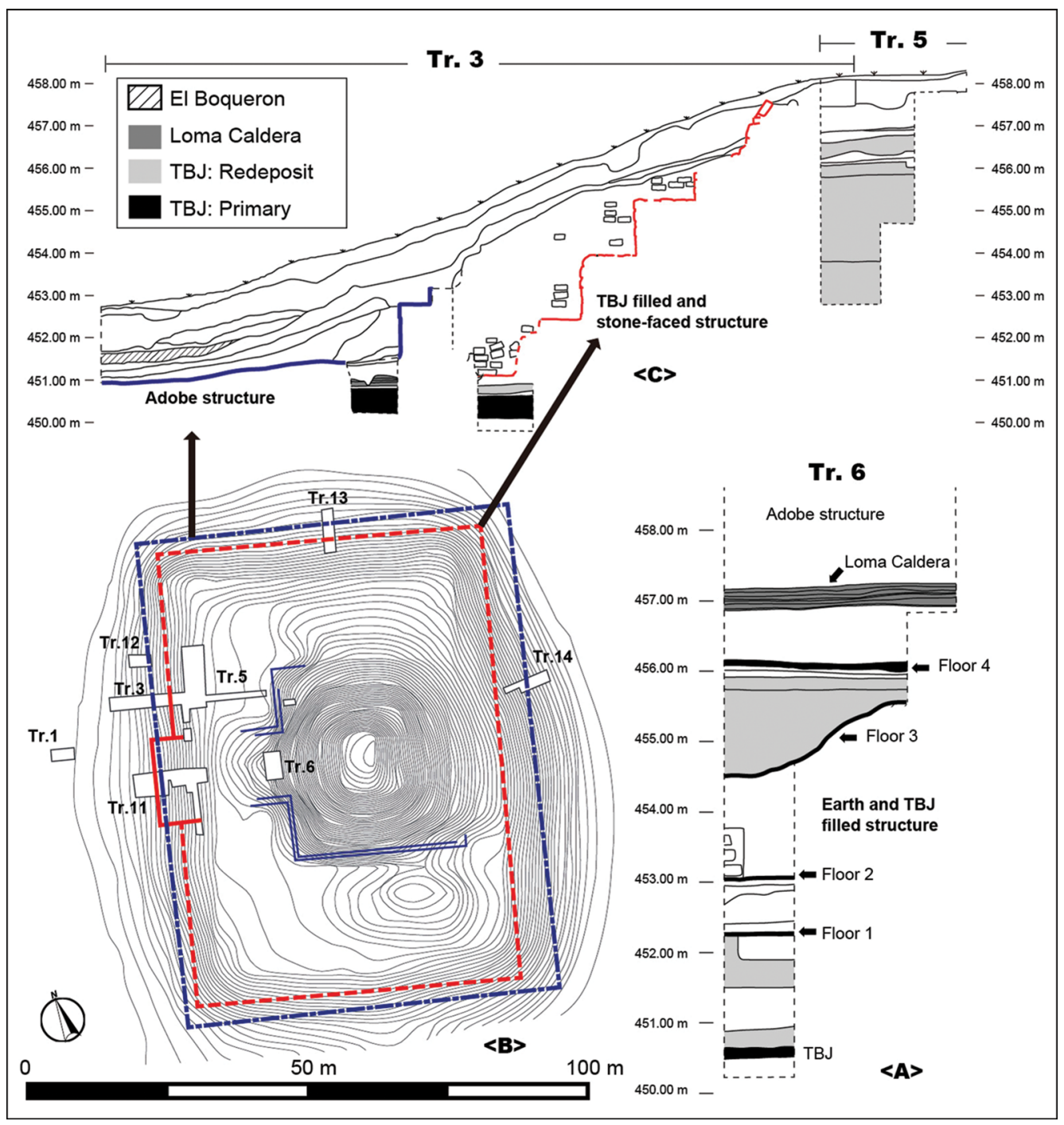

Figure 3. Plan and sections of the Campana structure at San Andrés (figure by A. Ichikawa).

Excavations reveal that the next building phase was a platform with approximately $5 \mathrm{~m}$ of TBJ tephra fill, faced by cut stone blocks (Figures 3B-C \& 5A-C). Only four small ceramic sherds have been recovered here, indicating that the TBJ tephra was carefully separated from other soils and materials before being redeposited. The TBJ-filled and stone-faced structure comprised a platform that measured approximately $80 \times 55 \mathrm{~m}$, and $6 \mathrm{~m}$ in height, on which there may have been a superstructure. The volume calculation of the platform is at least $24054 \mathrm{~m}^{3}$, which accounts for approximately 75 per cent of the total volume of the Campana structure. The platform had four terraces, each approximately $1.5 \mathrm{~m}$ in height and $1-1.4 \mathrm{~m}$ in width. On the west side of the structure was a 16m-wide central staircase (Figure 5A). The facing stones are mainly volcanic tuff blocks, possibly extracted from the west side of the San Salvador volcanic complex.

(C) The Author(s), 2021. Published by Cambridge University Press on behalf of Antiquity Publications Ltd 


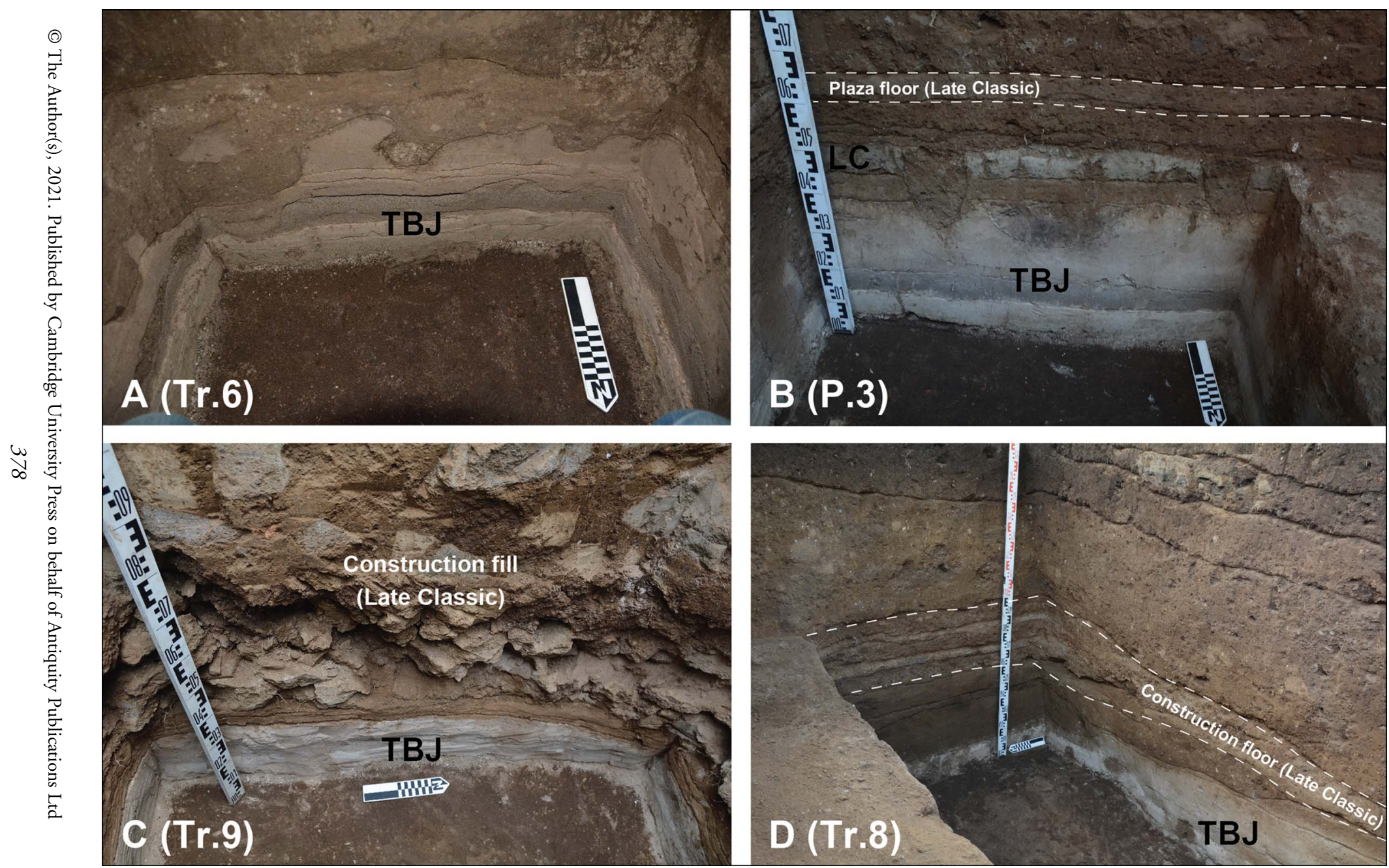

Figure 4. Tierra Blanca Joven tephra identified at San Andrés, showing different thickness of tephra found in different excavated areas: A) Trench 6 located in the Campana structure; B) Pit 3 located in the North Plaza; C) Trench 9 located in Structure 10; D) Trench 8 located in Structure 6 (photographs by A. Ichikawa). 


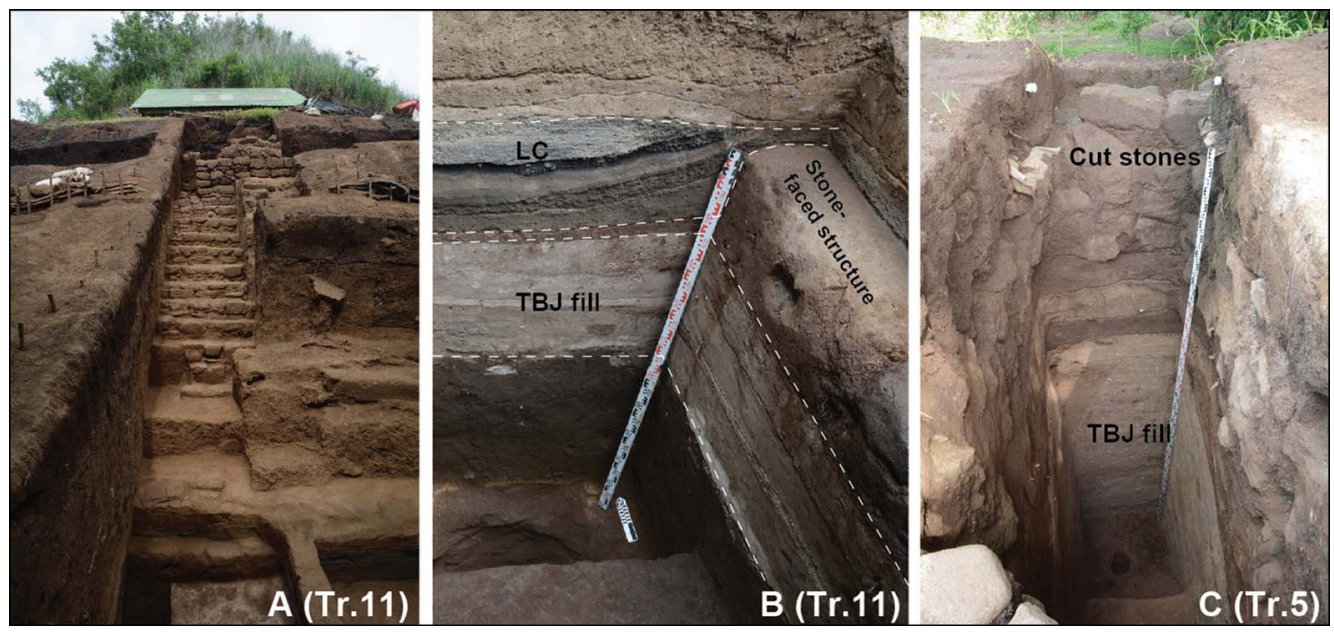

Figure 5. Stone-faced structure at San Andrés: A) central staircase; B) stratigraphic relationships between the primary Loma Caldera layer, the stone-faced structure and the TBJ fill; C) large quantity of TBJ fill under the cut stone blocks (photographs by A. Ichikawa).

Notably, the stone-faced structure is located stratigraphically below Loma Caldera tephra (Figure 5B). The Loma Caldera is situated some 6km north of San Andrés. As discussed below, this eruption has been radiocarbon dated to $c$. AD 620. The magnitude of the eruption was smaller than the TBJ event (Sheets 2012), although its volcanic deposits buried Cerén, which is located approximately $500 \mathrm{~m}$ south of the vent. The thickness of primary Loma Caldera tephra recorded in San Andrés averages approximately $0.2 \mathrm{~m}$ or less (Table S1). The Loma Caldera tephra found at San Andrés comprises two units: the lower part is an indurated, laminated, grey-brown ash layer, while the upper part is black scoria lapilli. Based on visual assessment, these units correspond to Units 3 and 4 reported at Cerén (Miller 2002: 21).

The stone-faced construction may be the only monumental public building in the valley that was constructed during the Early Classic period. Subsequently, a structure of adobe coated with mud plaster was built after the Loma Caldera eruption. Although further research is necessary, the available data indicate that the Acropolis-located to the south of the Campana structure-was constructed entirely using the same adobe and mud-plastering techniques (Boggs 1943; Amaroli 2015). This suggests contemporaneity with the adobe phase of the Campana structure. The stratigraphic, architectural and radiocarbon data indicate that the other public buildings, such as the North Plaza and the four rectangular structures surrounding it, were also built after the Loma Caldera eruption.

\section{Radiocarbon dating}

It is clear that the first monumental public building project at San Andrés was initiated after the TBJ eruption. Seventeen carbon samples from the Campana structure collected during the 2015-2019 seasons have been analysed using Accelerator Mass Spectrometry (AMS) radiocarbon dating and Bayesian modelling techniques (Figure 6; Figures S1, S2 and

(C) The Author(s), 2021. Published by Cambridge University Press on behalf of Antiquity Publications Ltd 


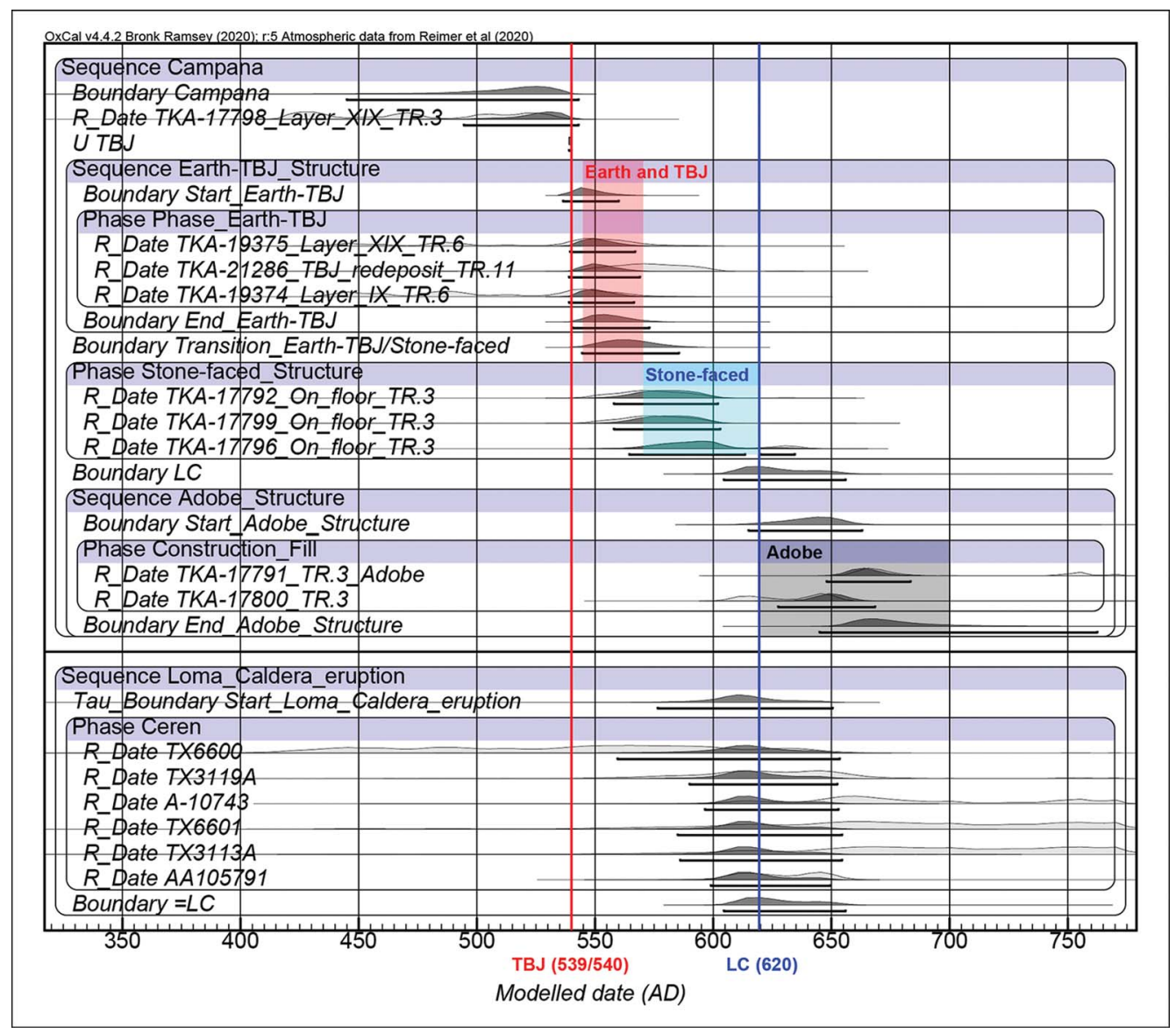

Figure 6. Summary of the results of Bayesian analysis of radiocarbon dates obtained from San Andrés and Cerén (figure by A. Ichikawa; based on dates calibrated using OxCal v4.4.2 and the IntCal20 atmospheric curve (Bronk Ramsey 2020; Reimer et al. 2020)).

Table S2; see the OSM). The dates are modelled in Oxcal v4.4.2 using the IntCal20 calibration curve (Bronk Ramsey 2020; Reimer et al. 2020). To calculate the date of the Loma Caldera eruption, previously published radiocarbon data from Cerén were used (Sheets 1983: 7; McKee 2002: 7; Slotten 2015: 72).

Carbon samples associated with the structure made with earth and TBJ fill are dated to $c$. cal AD 545-570. Although it is possible that these specific carbon samples are from before or during the eruption, the radiocarbon data suggest that construction began within decades of the TBJ eruption date. Carbon samples recovered from a terrace floor of the stone-faced structure are dated to $c$. cal AD 570-620_after the radiocarbon calibration curve plateau. This indicates that they are probably from after the TBJ eruption. Bayesian modelling suggests that the Loma Caldera eruption occurred $c$. cal AD 620. These data imply that a monumental building project (and renovation) happened within a few decades, and a maximum of 80 years, after the TBJ eruption.

(C) The Author(s), 2021. Published by Cambridge University Press on behalf of Antiquity Publications Ltd 


\section{Architectural energetic analysis}

Architectural energetic analysis provides crucial insight into labour investment and organisation (e.g. Abrams 1994; Webster \& Kirker 1995; Murakami 2010; Joyce et al. 2013). Estimating the labour investment for monumental public building projects at San Andrés in the post-TBJ eruption period provides important data about the human response to the catastrophic volcanic event. The volume of the stone-faced structure is estimated to be $24054 \mathrm{~m}^{3}$. This is a minimum estimate, since the presence of possible superstructures has yet to be determined. Similarly, the following calculation of energy costs excludes ongoing maintenance and renovation of the structure, so again, the true costs were probably higher. Other researchers using architectural energetic analysis in Mesoamerica have experienced similar complications (e.g. Joyce et al. 2013; Murakami 2019).

This study uses an approach that follows published procedures (Abrams 1994; Murakami 2010; Joyce et al. 2013). Here, two measures are used: total labour costs (person-days (p-d)), which is the number of people necessary for a task with time held constant; and per-capita labour costs (days per person $(d-p)$ ), which is the number of days necessary for a task with the number of people held constant (Murakami 2010: 162). Four separate steps are used to estimate the labour costs for: (1) procurement of raw materials (i.e. the earthen fill, TBJ tephra and the volcanic tuffs); (2) transport; (3) manufacture; and (4) construction or assembly (Abrams 1994: 43). Based on the surface area of the stone-faced structure and the estimated $0.5 \mathrm{~m}$ wall thickness, $1006 \mathrm{~m}^{3}$ of volcanic tuff was required to face the structure, and a total volume of earth and TBJ tephra for the construction fill is estimated at $23048 \mathrm{~m}^{3}$.

To estimate the labour investment cost of procuring raw materials, I use the following published measures of labour costs for procurement: $2.6 \mathrm{~m}^{3} / \mathrm{p}-\mathrm{d}$ for earthen fill and TBJ tephra, and $1.3 \mathrm{~m}^{3} / \mathrm{p}$-d for volcanic rocks (Murakami 2010: tab. 5.1). This results in 8865 $\mathrm{p}-\mathrm{d}$ for earth and TBJ tephra, and $1437 \mathrm{p}-\mathrm{d}$ for the cut stone. Thus, the total labour cost for procurement is $10302 \mathrm{p}-\mathrm{d}$. The transportation cost is calculated using the following formula (Aaberg \& Bonsignore 1975: 46):

$$
\text { Output }=Q \times \frac{1}{\frac{L}{V}+\frac{L}{V^{\prime}}} \times H
$$

$\mathrm{Q}$ is the load capacity. Ethnographic studies suggest that an average load is $22 \mathrm{~kg}$ - equivalent to $0.02 \mathrm{~m}^{3}$ (Abrams 1994: 48). L indicates the distance of raw materials from the construction site. Excavation data suggest that the earth and TBJ tephra may have been extracted from locations within $200 \mathrm{~m}$ of the Campana structure. Volcanic tuff was located on the ridges or slopes of volcanos surrounding the valley floodplain, particularly the western slope of the San Salvador volcanic complex, located around $10 \mathrm{~km}$ from the site. V is kilometres travelled per hour while bearing a load $(3 \mathrm{~km} / \mathrm{h})$. $\mathrm{V}^{\prime}$ is the unloaded return trip $(5 \mathrm{~km} / \mathrm{h})$ (Abrams 1994: 47). $\mathrm{H}$ is five hours per workday, based on field experiments (Erasmus 1965). As a result, the total transportation cost is estimated at $140975 \mathrm{p}-\mathrm{d}: 29175 \mathrm{p}-\mathrm{d}\left(0.79 \mathrm{~m}^{3} / \mathrm{p}-\mathrm{d}\right)$ for earth and TBJ tephra and $111800 \mathrm{p}-\mathrm{d}\left(0.009 \mathrm{~m}^{3} / \mathrm{p}-\mathrm{d}\right)$ for volcanic tuff.

The volcanic tuff required preparation before use. The total estimated labour investment required to prepare $0.13 \mathrm{~m}^{3} / \mathrm{p}-\mathrm{d}$ of facing stones (Murakami 2010: 202) is $7738 \mathrm{p}-\mathrm{d}$. The

(C) The Author(s), 2021. Published by Cambridge University Press on behalf of Antiquity Publications Ltd 
final consideration is construction or assembly. It is assumed that the cost of laying fill, such as earth, is insignificant, because it is subsumed into the transportation cost (Abrams 1994: 51). The labour cost for building a stone wall is $1.06 \mathrm{~m}^{3} / \mathrm{p}-\mathrm{d}$ (Murakami 2010: 210), yielding a figure of 949 p-d at San Andrés.

Using the above steps to calculate labour investment gives a total of $159964 \mathrm{p}-\mathrm{d}$ for the construction of the stone-faced structure. Table S3 shows the total $\mathrm{p}-\mathrm{d}$ in years needed to construct the stone-faced structure and per-capita labour cost, depending on the number of days and the size of the labour force. The estimation of population size at San Andrés is still uncertain due to limited data. Nevertheless, the data indicate that if 1000 labourers worked for 60 days per year (Abrams 1989: 73), the stone-faced structure would have taken three years to build, with a per-capita labour cost of $160 \mathrm{~d}$-p.

\section{Discussion and conclusion}

Growing archaeological evidence indicates that the monumental public building project at San Andrés was probably initiated within 5-30 years after the TBJ eruption, or within 80 years at the latest - that is, by the late sixth or early seventh century AD. This evidence supports the hypothesis of rapid recovery following the TBJ eruption (Dull et al. 2019), and is important, as it demonstrates that, counter to previous hypotheses, monumental architecture was constructed earlier than the mid-seventh century AD. Although the eruption rendered a large area uninhabitable (Dull et al. 2019: 14), evidence shows that people quickly returned to construct and renovate monumental architecture in an area entirely covered by TBJ tephra.

Two hypothetical scenarios could explain this rapid recovery process. The first is that certain populations in the valley-where agricultural fields were destroyed by the eruption-survived and moved to less-affected areas, such as the surrounding mountains. Following the eruption and the loss of agricultural fields, food-production strategies may have altered (Dull et al. 2019). Notably, ethnographic data reveal that, following the 1943 Parícutin eruption in Mexico, farmers planted maize and fruit trees on the previously unused, steeper slopes (Scarth 1999: 209). Moreover, the continuity of ceramic types across the region before and after the TBJ eruption may also support this hypothesis (Demarest 1988), with pre-existing populations maintaining a strong sense of place and commitment to a homeland (Sheets 2016: 153).

Another possibility is that following the eruption, the valley became depopulated and lost its cultural tradition, and was thereafter repopulated by immigrants from the Copán area of Honduras, such as the Ch'orti', rather than descendants of the local pre-eruption population. This may have resulted in similarities in architectural features and materials between Cerén and Copán (Sheets 2009: 67). Although it is difficult to verify this hypothesis archaeologically, the motivation behind the society's migration from the less-affected area (Copán) to the devastated and unfamiliar area (Cerén) must be considered. Alternatively, a mixed model can be considered, in which survivors took refuge in other less-affected, yet familiar regions beyond the valley, and were accompanied by immigrants upon their return. This scenario emphasises that social networks play an important role in the mitigation and recovery after a disaster (Sheets \& Cooper 2012: 14).

(C) The Author(s), 2021. Published by Cambridge University Press on behalf of Antiquity Publications Ltd 
The TBJ tephra may have been used for religious and functional purposes. In the Mesoamerican worldview, volcanos and mountains were recognised as sacred places (Fash \& López Luján 2009). As Sheets et al. (2015: 355) propose with the example of the sacbe (white road), which was created in Cerén using pure TBJ tephra, white ash emitted by the eruption may have been perceived to have powerful religious or cosmological significance. Thus, the use of TBJ tephra in the monumental buildings at San Andrés may have been an important symbol of shared religious veneration. Additionally, modern civil engineers recognise the excellent compaction properties of TBJ tephra (Sheets et al. 2015: 354). Ancient builders were also probably familiar with these properties, and it may have been an important factor in their decision to use the material in the monumental building at San Andrés.

The estimated labour costs for the Campana structure provide useful information about the nature of the human response to the TBJ eruption. The stone-faced platform accounts for 75 per cent of the total volume of the Campana structure. Radiocarbon dates and stratigraphic data indicate that the initial construction, renovations and completion of the stone-faced structure occurred within a maximum of 80 years of the TBJ eruption. Although estimating the pre-/post-TBJ event population of the valley remains challenging due to limited data, the labour investment required for the stone-faced structure is impressive. As Dull et al. (2019: 12) suggest, the populations around the volcano may have declined substantially following the eruption. If the size of the workforce was 500-1500 people, the per-capita labour cost, surprisingly, is similar to that of the Sun Pyramid at Teotihuacan (351.33 for the Miccaotli phase and 109.59 for the Early Xolalpan phase; Murakami 2019: 273). The societies in the Zapotitán Valley, including at San Andrés, however, were probably less complex than at Teotihuacan, and there is little evidence to suggest state-oriented or elite control of labour through coercion in the valley. Rather, I believe that survivors and/or re-settlers in the Zapotitán Valley may have constructed the monumental public building at San Andrés in response to the massive TBJ eruption. As others have argued (e.g. Joyce et al. 2013), this work might have had a religious purpose, enabling social integration, as well as creating a sense of community among participants during the difficult times following the eruption. Furthermore, local leaders or rulers may have emerged and reinforced their own power through this construction process. The devastating first-century AD eruption of Popocatépetl in Puebla, Mexico, forced a population movement; these refugees contributed to developing the largest urban centre of Mesoamerica: Teotihuacan (Plunket \& Uruñuela 2005: 100). But whereas Teotihuacan was developed by displaced migrants in an area unaffected by the eruption, San Andrés was transformed into the valley's primary centre by returning survivors and/or re-settlers.

Notably, an increased investment in monumental public buildings at San Andrés was also observed after the Loma Caldera eruption. The total volume of the Acropolis (processed using Surfer software) is $91757 \mathrm{~m}^{3}$-almost three times the total volume of the Campana structure. The structure was built using large quantities of adobe, indicating more intensive labour investment than required in the previous period. Radiocarbon and stratigraphic data show that the Campana structure was renovated using new adobe and mud-plaster construction techniques (Figure 6). The Acropolis and other adobe structures were also constructed in the decades immediately following the Loma Caldera eruption, and San Andrés became the primary centre of the Zapotitán Valley. Presumably, San Andrés may have been a focal point

(C) The Author(s), 2021. Published by Cambridge University Press on behalf of Antiquity Publications Ltd 
of the materialised memory of previous catastrophic eruptions and regional, community identity. This phenomenon suggests an objective of future research should be investigation of the potential correlation between the volcanic eruption and political and economic processes.

Massive volcanic eruptions may have directly or indirectly changed the course of Mesoamerican history, as well as that of other ancient civilisations (e.g. Plunket \& Uruñuela 2005; Manning et al. 2017; McConnell et al. 2020). The effects of volcanic events vary widely depending on the direction, distance from the volcano, ecological setting, thickness and type of tephra and cultural and social conditions (Sheets 2012). Thus, further investigation is required of more sites affected by volcanic events, including other major centres such as Chalchuapa and Cara Sucia, as well as smaller sites. To verify the specific quick-recovery hypothesis described above, future research will need to address mitigation and food-procurement strategies, and will require further archaeological materials, isotopic studies of human remains and detailed chronological data from the region. The research presented here contributes important new information to the discussion about human creativity, innovation, adaptation, resilience and vulnerability in the face of abrupt environmental change.

\section{Acknowledgements}

I am grateful to the Dirección de Arqueología de la Dirección Nacional de Patrimonio Cultural, Ministerio de Cultura, El Salvador, for their considerable support and permission to conduct research at San Andrés. I also thank the Laboratory of Radiocarbon Dating at the University of Tokyo's Museum for dating the carbon samples. Likewise, I am grateful to Arthur Joyce, Payson Sheets, Erlend Johnson, Errin Weller and Alexandra Kulenguski for their thoughtful comments on earlier drafts of this manuscript. Finally, I express my gratitude to the reviewers for their insightful comments and suggestions, which helped improve the article significantly.

\section{Funding statement}

The fieldwork at San Andrés and the radiocarbon dating were supported by grants from the Japan Society for the Promotion of Science (\#26101003, 19H05734, 19H01347 and 19K13400) and the Mitsubishi Foundation (\#29201).

\section{Supplementary material}

To view supplementary material for this article, please visit https://doi.org/10.15184/aqy. 2021.21

\section{References}

Aaberg, S. \& J. Bonsignore. 1975. A consideration of time and labor expenditure in the construction process at the Teotihuacan Pyramid of the Sun and the Poverty Point Mound, in J. Graham \& R. Heizer (ed.) Three papers on Mesoamerican archaeology: 40-78. Berkeley: University of California.

Abrams, E. 1989. Architecture and energy: an evolutionary perspective. Archaeological Method and Theory 1: 47-88. 
- 1994. How the Maya built their world: energetics and ancient architecture. Austin: University of Texas Press.

Amaroli, P. 1996. Investigaciones arqueológicas en el área de nuevas instalaciones en el Parque Arqueológico San Andrés. Unpublished report submitted to the Patronato Pro-Patrimonio Cultural, San Salvador, El Salvador.

- 2015. Arqueología de El Salvador. El Salvador: FUNDAR.

Begley, C. et al. 1997. Proyecto arqueológico San Andrés: informe 1997. Unpublished report submitted to the Patronato Patrimonio Cultural, San Salvador, El Salvador.

BLACK, K.D. 1983. The Zapotitán Valley archaeological survey, in P.D. Sheets (ed.) Archaeology and volcanism in Central America: the Zapotitán Valley of El Salvador: 62-97. Austin: University of Texas Press.

BogGs, S.H. 1943. Notas sobre las excavaciones en la Hacienda "San Andrés", Departamento de la Libertad. Tzumpame 3: 104-26.

Bronk Ramsey, C. 2020. Oxcal v4.4.2. Available at: http://c14.arch.ox.ac.uk (accessed 20 December 2020).

Chandler, S.M. 1983. Excavations at the Cambio site, in P.D. Sheets (ed.) Archaeology and volcanism in Central America: the Zapotitán Valley of El Salvador: 98-118. Austin: University of Texas Press.

Coombes, P. \& K. BArber. 2005. Environmental determinism in Holocene research: causality or coincidence? Area 37: 303-11.

https://doi.org/10.1111/j.1475-4762.2005. 00634.x

Cooper, J. \& P.D. SheEts (ed.). 2012 Surviving sudden environmental change: answers from archaeology. Boulder: University Press of Colorado. https://doi.org/10.2307/j.ctt1wn0rbs

Demarest, A.A. 1988. Political evolution in the Maya borderlands: the Salvadoran frontier, in E.H. Boone \& G.R. Willey (ed.) The south-east classic Maya zone: 335-94. Washington, D.C.: Dumbarton Oaks Research Library.

Dull, R.A., J.R. Southon \& P.D. Sheets. 2001. Volcanism, ecology and culture: a reassessment of the Volcán Ilopango TBJ eruption in the southern Maya realm. Latin American Antiquity 12: 25-44. https://doi.org/10.2307/971755

Dull, R.A. et al. 2010. Did the Ilopango TBJ eruption cause the $\mathrm{AD} 536$ event? AGU Fall Meeting, Abstracts 1: 2370.
- 2019. Radiocarbon and geologic evidence reveal Ilopango volcano as source of the colossal 'mystery' eruption of 539/40 CE. Quaternary Science Reviews 222: 105855. https://doi.org/10.1016/j.quascirev.2019.07.037

Erasums, C.J. 1965. Monument building: field experiments. Southwestern Journal of Anthropology 21: 277-301.

https://doi.org/10.1086/soutjanth.21.4. 3629433

FASH, W.L. \& L. López Luján (ed.). 2009. The art of urbanism: how Mesoamerican kingdoms represented themselves in architecture and imagery.

Washington, D.C.: Dumbarton Oaks Library and Collection.

Ferrés, D. et al. 2011. Three thousand years of flank and central vent eruptions of the San Salvador volcanic complex (El Salvador) and their effects on El Cambio archaeological site: a review based on tephrostratigraphy. Bulletin of Volcanology 73: 833-50. https://doi.org/10.1007/s00445-011-0465-0

GunN, J. (ed.). 2000. The years without summer: tracing $A D 536$ and its aftermath (British Archaeological Reports International Series 872). Oxford: Archaeopress. https://doi.org/10.30861/9781841710747

IChikawa, A. \& J.M. Guerra Clará. 2018. Producción de alfarería en el sitio arqueológico San Andrés, El Salvador. Journal of Humanities, Nagoya University 1: 433-46.

Joyce, A.A, M.N. LeVine \& S.B. Barber. 2013. Place-making and power in the terminal formative: excavations on Río Viejo's Acropolis, in A.A. Joyce (ed.) Polity and ecology in Formative period coastal Oaxaca: 135-63. Boulder: University Press of Colorado. https://doi.org/10.5876/9781607322023.c05

Kintigh, K.W. et al. 2014. Grand challenges for archaeology. American Antiquity 79: 5-24. https://doi.org/10.7183/0002-7316.79.1.5

Kosakowsky, L.J., F. Estrada Belli \& P. Pettitt. 2000. Preclassic through Postclassic: ceramics and chronology of the south-eastern Pacific coast of Guatemala. Ancient Mesoamerica 11: 199-215. https://doi.org/10.1017/S0956536100112027

LoHsE, J.C. et al. 2018. Late Holocene volcanic activity and environmental change in Highland Guatemala. Quaternary Science Reviews 191: 378-92. https://doi.org/10.1016/j.quascirev.2018.05.014

(C) The Author(s), 2021. Published by Cambridge University Press on behalf of Antiquity Publications Ltd 
Manning, J.G. et al. 2017. Volcanic suppression of Nile summer flooding triggers revolt and constrains interstate conflict in ancient Egypt. Nature Communications 8: 900. https://doi.org/10.1038/s41467-017-00957-y

McConnell, J.R. et al. 2020. Extreme climate after massive eruption of Alaska's Okmok volcano in $43 \mathrm{BCE}$ and effects on the late Roman Republic and Ptolemaic Kingdom. Proceedings of the National Academy of Sciences of the USA 117: 15443-49. https://doi.org/10.1073/pnas.2002722117

McKeE, B.R. 2002. Appendix 1A: radiocarbon dating and chronology, in P.D. Sheets (ed.) Before the volcano erupted: the ancient Cerén village in Central America: 7-8. Austin: University of Texas Press.

- 2007. Volcanism, household archaeology, and formation processes in the Zapotitán Valley, El Salvador. Unpublished PhD dissertation, University of Arizona.

- 2011. Evidencia del uso agrícola del sitio San Andrés durante el período protoclásico. $\mathrm{La}$ Universidad 14-15: 305-15.

Mejía, J. 1984. Las ruinas de San Andrés: excavaciones en la estructura No. 7. Flama 14 (48): 33-47.

MilLer, C.D. 2002. Volcanology, stratigraphy, and effects on structures, in P.D. Sheets (ed.) Before the volcano erupted: the ancient Cerén village in Central America: 11-23. Austin: University of Texas Press.

Murakami, T. 2010. Power relations and urban landscape formation: a study of construction labor and resources at Teotihuacan. Unpublished $\mathrm{PhD}$ dissertation, Arizona State University.

-2019. Towards a multiscalar comparative approach to power relations: political dimensions of urban construction at Teotihuacan and Copán, in L. McCurdy \& E.M. Abrams (ed.) Architectural energetics in archaeology: analytical expansions and global explorations: $265-88$. New York \& London: Routledge.

Pedrazzi, D. et al. 2019. The Ilopango Tierra Blanca Joven (TBJ) eruption, El Salvador: volcano stratigraphy and physical characterization of the major Holocene event of Central America. Journal of Volcanology and Geothermal Research 377: 81-102.

https://doi.org/10.1016/j.jvolgeores.2019.03.006

Plunket, P. \& G. URuñuela. 2005. Recent research in Puebla prehistory. Journal of Archaeological
Research 13: 89-127. https://doi.org/10.1007/s10804-005-2485-5

Reimer, P.J. et al. 2020. The IntCal20 Northern Hemisphere radiocarbon age calibration curve (0-55 cal kBP). Radiocarbon 62: 725-57. https://doi.org/10.1017/RDC.2020.41

SCarth, A. 1999. Vulcan's fury: man against the volcano. New Haven (CT): Yale University Press.

SHARER, R.J. 1978. The prehistory of Chalchuapa, El Salvador, vol. I-III. Philadelphia: University of Pennsylvania Press.

Sheets, P.D. (ed.). 1983. Archaeology and volcanism in Central America: the Zapotitán Valley of El Salvador. Austin: University of Texas Press.

- 2002. Before the volcano erupted: the ancient Cerén village in Central America. Austin: University of Texas Press.

- 2009. Who were those Classic period immigrants into the Zapotitán Valley, El Salvador? in B.E. Metz, C.L. McNeil \& K.M. Hull (ed.) The Ch'orti' Maya area: past and present: 61-77. Gainesville: University Press of Florida.

-2012. Responses to explosive volcanic eruptions by small to complex societies in ancient Mexico and Central America, in J. Cooper \& P.D. Sheets (ed.) Surviving sudden environmental change: answers from archaeology: 43-66. Boulder: University Press of Colorado.

- 2016. Thoughts and observations on volcanic activity and human ecology. Quaternary International 394: 152-54. https://doi.org/10.1016/j.quaint.2015.08.070

SheEts, P.D. \& J. Cooper. 2012. Learning to live with the dangers of sudden environmental change, in J. Cooper \& P.D. Sheets (ed.) Surviving sudden environmental change: answers from archaeology: 1-18. Boulder: University Press of Colorado.

SheEts, P.D. et al. 2015. The sociopolitical economy of an ancient Maya village: Cerén and its Sacbe. Latin American Antiquity 26: 341-61. https://doi.org/10.7183/1045-6635.26.3.341

SLotten, V. 2015. Paleoethnobotanical remains and land use associated with the Sacbe at the ancient Maya village of Joya de Cerén. Unpublished MA dissertation, University of Cincinnati.

Webster, D. \& J. Kirker. 1995. Too many Maya, too few buildings: investigating construction potential at Copán, Honduras. Journal of Anthropological Research 51: 363-87. https://doi.org/10.1086/jar.51.4.3630143

(C) The Author(s), 2021. Published by Cambridge University Press on behalf of Antiquity Publications Ltd 